\title{
Cuspal Ridges of Deciduous Upper Second Molars in Japanese Subjects
}

\author{
Mitsuo SeKIKAWA ${ }^{1)}$, Eisaku KANAZAWA ${ }^{1)}$, Tadashi OzaKi ${ }^{1)}$ and \\ L.C. RICHARDS ${ }^{2)}$ \\ 1) Department of Anatomy, Nihon University School of Dentistry at Matsudo \\ 2) Department of Dentistry, The University of Adelaide, Adelaide, Australia
}

\begin{abstract}
The occlusal surfaces of deciduous upper second molars were photographed by moiré contourography using the standard trigonal plane. The ridges of a cusp, comprising a central ridge and the mesial and distal accessory ridges, were identified by the patterns of the moiré fringes. The central ridge was present on all cusps except for the hypocone in both sexes. Frequencies of the two accessory ridges on trigonal cusps exceeded $60 \%$ except for the distal accessory ridge on the metacone. The mesial accessory ridge on the metacone was significantly more common in females than in males, but the running pattern of the cuspal ridges showed little difference between sexes. The oblique ridge of the deciduous molar was well developed compared with that of the permanent first molar. This ridge was observed in all subjects, but its height and structural components varied remarkably. A small tubercle on the oblique ridge was sometimes observed, usually located on the metacone side. This tubercle was similar to the metaconule in its position and morphology. Intercuspal distances showed larger mean values in the molars with a metaconule than those without. This implied that the overall crown size was affected by the degree of development of some crown components, such as the ridges and tubercles.
\end{abstract}

Keywords Oblique ridge, Metaconule, Moiré contourography, Cusp height, Odontometry

\section{Introduction}

There are three basic types of cuspal ridges on the occlusal surfaces of human molars, namely a central ridge, and mesial and distal accessory ridges. The running pattern and the incline of the cuspal ridge are particularly important, not only in an anatomical sense (LAVELLE, 1978;
SAKURA, 1980; SEKIKAWA et al., 1987) but also in clinical dentistry (ASH, 1984; JAARADA et al., 1978). However, a detailed quantitative description of the cuspal ridges of deciduous teeth has not been fully developed because of both the difficulty in collecting suitable attrition-free teeth and the lack of an effective technique for measuring and recording occlusal morphology.

Article No. 8920 Received October 19, 1989 
We have already reported sex differences in the micro-relief of the tooth crown, the relation between the height of cusps and the size of the tooth and the detailed running pattern of the cuspal ridges of the permanent first molars using three-dimensional moiré contourography (OZAKI et al., 1984, 1987; KANAZAWA et al., 1983, 1984, 1988; SEKIKAWA et al., 1986, 1987, 1988). In the present article, the distribution of the running pattern of cuspal ridges of deciduous upper second molars was investigated by moiré photographs with the aid of a microcomputer, and the results obtained were compared with those of the upper first molars reported previously by SEKIKAWA et al. (1987).

\section{Materials and Methods}

In this study plaster dental casts of the deciduous upper right second molars of Japanese children who showed negligible attrition were obtained using vinyl silicone impression material. The sample consisted of 22 boys and 31 girls ranging in age from 2 to 3 years. All teeth had 4 cusps belonging to 4 or 4 - type (Dahlberg, 1949 ) and were free of caries or anomalies.

Mesiodistal and buccolingual crown diameters were obtained from each of the plaster casts using a digital caliper to an accuracy of $0.05 \mathrm{~mm}$ which is a convention usually followed in dental anthropology.

The occlusal surfaces of the molars were photographed by moiré contourography. The details of the moiré apparatus and the photographic technique involved have already been published (OZAKI et al., 1984).

The moiré photograph of each tooth was enlarged 8 times and used for identification of the three cuspal ridges described above. The average distribution of the running pattern of the cuspal ridges was obtained by the following method: The moiré photograph was placed on the digitizer (OSCON SS-4000) connected to a microcomputer into which coordinate values of the points of cuspal tips were entered at an accuracy of $0.02 \mathrm{~mm}$. A mesh composed of the standardized parallelogram was then constructed using horizontal and oblique lines (Fig. 1). The horizontal grid line was parallel to a line passing through the paracone and metacone and spaced at regular intervals one twenty-fifth of the distance between the paracone and metacone. The oblique grid line was made parallel to a line passing through the paracone and protocone spaced at regular intervals one thirty-fifth of the distance between the paracone and protocone. The mesh obtained, therefore, was independent of the tooth size. The cuspal ridges were traced using the digitizer and then the frequency with which each of the spaces in the mesh was occupied by a part of each ridge was determined. The cuspal ridge information contained in the mesh (matrix) was gathered, and an average distribution of the running pattern of the cuspal ridges was determined, representing the ratio of appearance in that particular mesh.

The heights of 11 reference points were re-

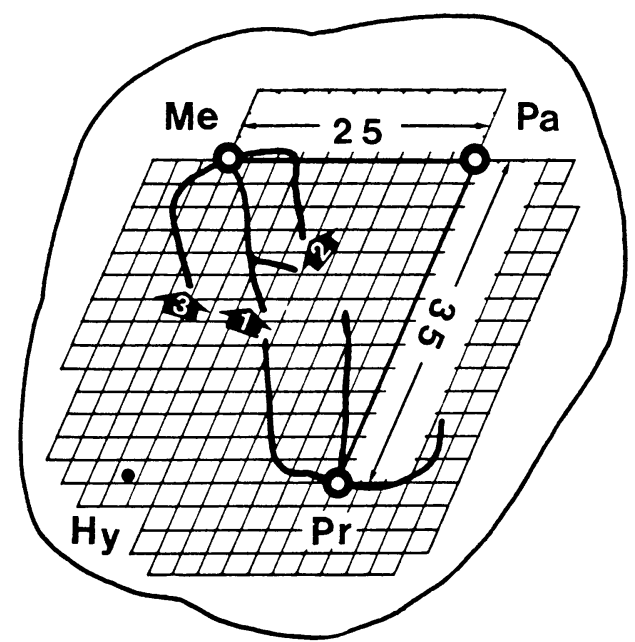

Fig. 1. Method of construction of the mesh using the standardized parallelograms. 1, central ridge; 2 , mesial accessory ridge; 3 , distal accessory ridge. 
corded by counting the number of contour lines from the deepest point of the occlusal surface (fossa mesiobuccalis) to the landmark concerned. These points were located as follows: $\mathrm{Pa}, \mathrm{Me}, \mathrm{Hy}$ and $\mathrm{Pr}$ are the cusp tips of paracone, metacone, hypocone and protocone, respectively; point a is the deepest point on the oblique ridge; points $b$ and $\mathrm{d}$ are the deepest points on the mesial and distal marginal ridges, respectively; points $\mathrm{c}$ and e are the deepest points in the intercusp cutting edges joining the two buccal and two lingual cusps, respectively; fdl (fossa distolingualis) is the deepest point in the distal fossa. Intercuspal distances were calculated from the coordinate values representing each of the cusp tips.

\section{Results}

Table 1 shows the frequency of occurrence for each of the three ridges on each cusp. The central ridge was present in all subjects, male and female, on all cusps except the hypocone. In both males

Table 1. Frequencies of cuspal ridges on deciduous second molars

\begin{tabular}{llllll}
\hline & & \multicolumn{3}{c}{ Males } & \multicolumn{3}{c}{ Females } \\
Cusp ridges & No. obs. & $(\%)$ & No. obs. & $(\%)$ \\
\hline Pa & 1 & 22 & $(100)$ & 31 & $(100)$ \\
& 2 & 18 & $(82)$ & 26 & $(83)$ \\
& 3 & 19 & $(86)$ & 23 & $(74)$ \\
& & & & & \\
$\operatorname{Pr}$ & 1 & 22 & $(100)$ & 31 & $(100)$ \\
& 2 & 18 & $(82)$ & 28 & $(90)$ \\
& 3 & 22 & $(100)$ & 31 & $(100)$ \\
& & & & & \\
Me & 1 & 22 & $(100)$ & 31 & $(100)$ \\
& 2 & 14 & $(64)$ & 28 & $(90)^{*}$ \\
& 3 & 13 & $(59)$ & 16 & $(51)$ \\
& & & & & \\
Hy & 1 & 10 & $(45)$ & 8 & $(58)$ \\
& 2 & 1 & $(5)$ & 2 & $(6)$ \\
& 3 & 1 & $(5)$ & 3 & $(9)$ \\
\hline
\end{tabular}

$1=$ central ridge

$2=$ mesial accessory ridge

$3=$ distal accessory ridge

* = significant sex difference $(p<0.05)$ and females the frequencies of the mesial and distal accessory ridges on paracone, protocone and metacone cusps exceeded $50 \%$. For the mesial accessory ridge of the metacone only, the frequencies differed significantly between males and females $(p<0.05)$.
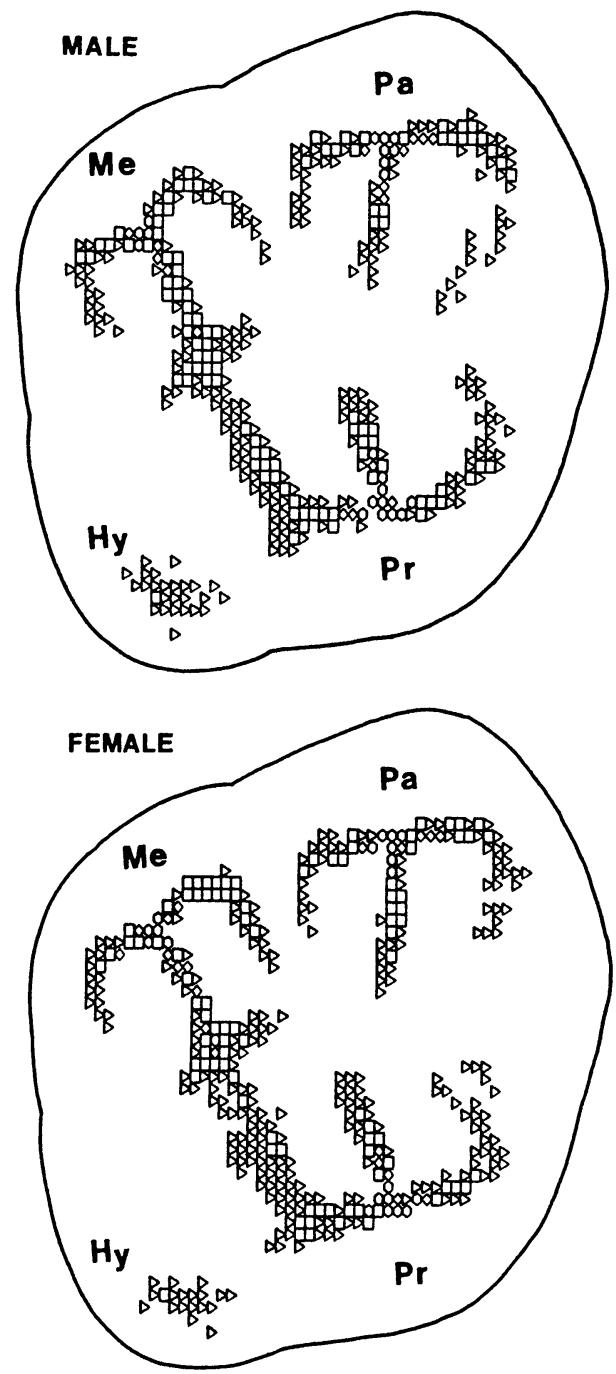

Fig. 2. The distribution of the running pattern of the cuspal ridges. Symbols denote the frequency of appearance of part of the ridge in each mesh space: $\triangleright=30-49 \% ; \quad \square=50-69 \% ; \diamond=70-89 \%, \quad 0=>90 \%$, respectively. 
The average distribution of the running pattern of the cuspal ridges is graphically represented in Fig. 2. These patterns showed little difference between sexes; the central ridge of the paracone ran obliquely from the cuspal tip in the distolingual direction while that of protocone ran distobuccally and that of metacone ran mesiolingually. The two accessory ridges tended to be parallel to the central ridge in each respective cusp. However, there was no regular running pattern of the cuspal ridges of the hypocone compared with those of the trigonal cusps. The variability of the running pattern of the ridges within a cusp was the highest in the hypocone and the lowest in both the paracone and protocone.

An apparent running pattern of the oblique ridge was observed in both males and females (Fig. 2). The oblique ridge is formed by continuation of the central ridge of the metacone and the distal accessory ridge of the protocone. The deepest point of the oblique ridge was shallower than the central groove, forming a saddle-like structure. The mean height of this point was 0.93 $\mathrm{mm}(\mathrm{SD}=0.12)$ in males and $0.93 \mathrm{~mm}$ $(\mathrm{SD}=0.19)$ in females.

A small tubercle on the oblique ridge was sometimes observed, which was usually located on the metacone side. This tubercle was similar to the metaconule in its position and morphology (Fig. 3). In the present study there was no significant sex difference in its frequency of appearance. Therefore, the developmental degree of the metaconule was classified into three grades from moiré contour patterns; Pronounced $(++)$, metaconule was well developed, like a cusp, resulting in at least one closed moiré fringe; Weak $(+)$, metaconule developed but without a clear tip and some minute ridges running from the tubercle to the deepest part of the occlusal surface. Absent ( - ), no tubercle and no minute ridges. Table 2 shows the heights of crown features, intercuspal distances and crown size according to the three categories of metaconule development. The largest mean height measures

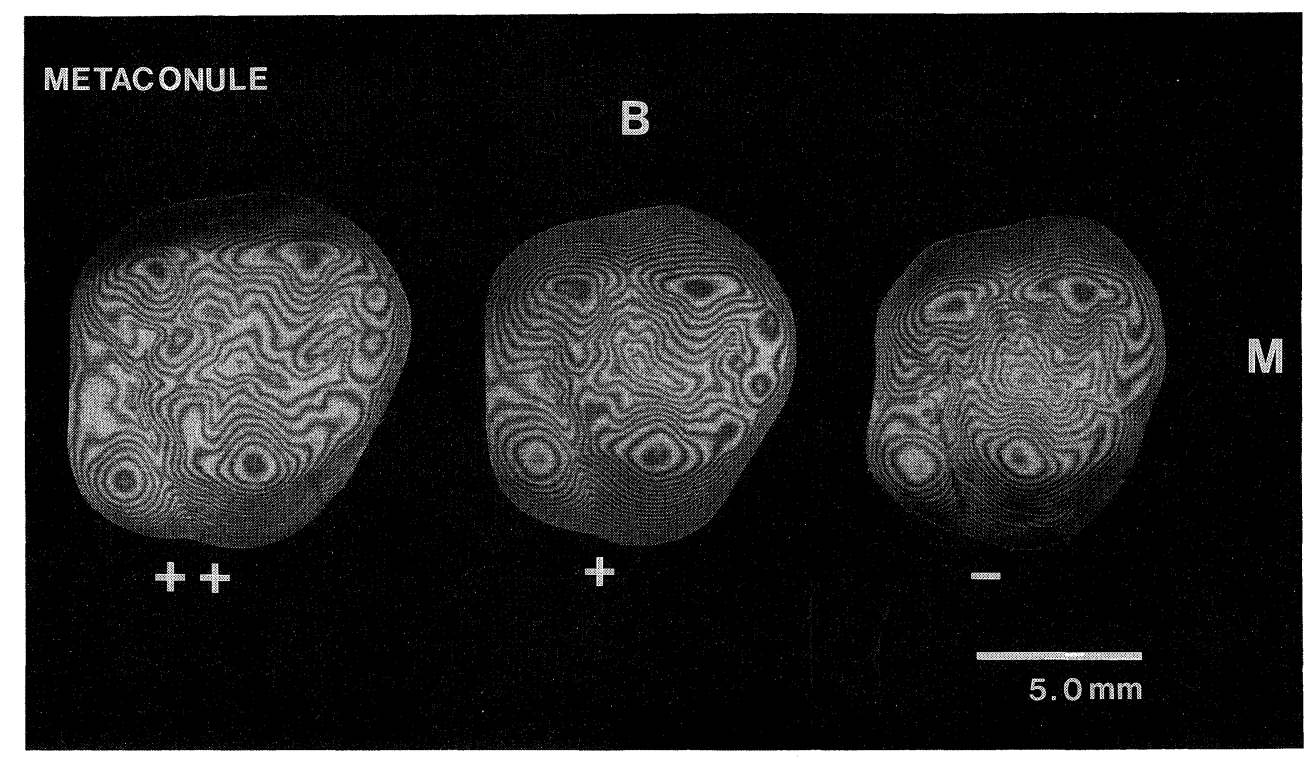

Fig. 3. Metaconule expression through Pronounced $(++)$, Weak $(+)$ and Absent $(-)$. M, mesial; B, buccal. 
Table 2. Means and S.D. of a group with and without metaconule ( $\mathrm{mm}$ )

\begin{tabular}{|c|c|c|c|c|c|c|}
\hline \multirow[b]{2}{*}{ Development } & \multicolumn{2}{|c|}{$++(n=16)$} & \multicolumn{2}{|c|}{$+(n=29)$} & \multicolumn{2}{|c|}{$-(n=8)$} \\
\hline & Mean & S.D. & Mean & S.D. & Mean & S.D \\
\hline \multicolumn{7}{|l|}{ Heights } \\
\hline 3 cusps & 2.11 & .21 & 2.16 & 12 & $\# 2.28$ & .18 \\
\hline $\mathrm{Hy}$ & 0.77 & .30 & 0.86 & .29 & $\# 0.94$ & .26 \\
\hline $\mathrm{a}$ & 1.23 & .17 & 1.23 & .16 & $\# 1.29$ & .11 \\
\hline$b$ & 1.24 & .23 & 1.23 & .25 & $\# 1.29$ & .25 \\
\hline $\mathrm{c}$ & 0.72 & .13 & 0.83 & .14 & $\# 0.89$ & .19 \\
\hline $\mathrm{d}$ & 1.91 & .25 & 1.96 & .32 & $\# 2.08$ & .32 \\
\hline $\mathrm{e}$ & 1.44 & .25 & 1.56 & .34 & $\# 1.61$ & .20 \\
\hline fdl & 2.13 & .18 & 2.23 & .24 & $\# 2.34$ & .25 \\
\hline
\end{tabular}

Intercuspal distances

$\begin{array}{lrlllrl}\text { Pr-Pa } & \# 5.69 & .43 & 5.41 & .33 & 5.43 & .18 \\ \mathrm{Me}-\mathrm{Pa} & 4.06 & .32 & 4.14 & .36 & \# 4.36 & .54 \\ \mathrm{Me}-\mathrm{Pr} & \# 5.94 & .44 & 5.44 & .45 & 5.36 & .32^{*} \\ \mathrm{Hy}-\mathrm{Pa} & \# 7.82 & .42 & 7.58 & .43 & 7.71 & .41 \\ \mathrm{Hy}-\mathrm{Pr} & \# 3.73 & .30 & 3.55 & .31 & 3.52 & .31 \\ \mathrm{Hy}-\mathrm{Me} & \# 5.83 & .45 & 5.34 & .40 & 5.30 & .31^{*}\end{array}$

Overall crown size

\begin{tabular}{lrrrrrr} 
MD & $\# 9.66$ & .55 & 9.40 & .52 & 9.50 & .37 \\
BL & $\# 10.01$ & .49 & 9.75 & .49 & 9.80 & .27 \\
\hline$++=$ & group with metaconule developed over 0.1 & $\mathrm{~mm}$ in height (Pronounced) \\
+ & $=$ group with metaconule developed under 0.1 & $\mathrm{~mm}$ in height (Weak) \\
$-\quad$ & $=$ group without metaconule (Absent) \\
$\# \quad=$ the largest mean value among three groups \\
$* \quad=$ significant mean difference between the smallest and largest groups $(\mathrm{p}<0.05)$
\end{tabular}

were seen in the absent metaconule group while the largest mean intercuspal distances and mesiodistal and buccolingual crown diameters (except for the distance between metacone and paracone) were seen in the Pronounced metaconule group. However, these mean differences were insignificant except for fossa distolingualis (fdl) height and two intercuspal distances, metacone-protocone (Me-Pr) and hypocone-metacone (Hy-Me).

Symbols in Figure 2 represent a frequency of appearance of over $30 \%$ in each space of the mesh. It was found that there was a tendency for a large number of symbols in the hypocone to appear in males compared with those in females. Moreover, the continuation of these symbols representing each ridge was clearer in males than in females, particularly for the mesial accessory ridge of the protocone.

\section{Discussion}

The molar cuspal ridges are important in research fields including dental morphology and anthropology, as well as in clinical dentistry. However, information about the ridges is limited to frequencies and qualitative descriptions. The 
present authors have previously obtained photographs of the occlusal surface of molars with fine moiré contour lines, which can be used to visualize the micro-relief of the tooth crown and the actual running pattern of the cuspal ridges of upper and lower first molars in the Japanese population. The frequencies of the cuspal ridges in Japanese subjects has already been reported by KAMIJOU (1977) who studied the permanent dentition by simple observation. However, a quantitative description of the cuspal ridges of the deciduous dentition in Japanese has not been reported previously.

The terminology used to describe the cuspal ridge seemed to be a little confusing. A system applicable for common use in dental anatomy should be one in which obscure expressions were removed (BUTLER, 1955). In the present study, the cuspal ridges are described as consisting of central ridges which arise from the tips of the cusps and pass down toward the area of the occlusal fossa, and two accessory ridges which arise from the cutting edges of the mesial and distal sides of cusps are named according to their location, the mesial and distal accessory ridge, respectively.

A sex difference was observed only in the frequency of appearance of the mesial accessory ridge of the metacone. The frequency of this ridge was higher in females than in males. OZAKI et al. (1988) studied the occlusal surface of the deciduous upper second molar in three dimensions with the aid of moiré contourography. They also found that the intercuspal distance between the paracone and metacone was significantly greater in females than in males. In the permanent upper first molar, the distal accessory ridge of the metacone was more frequently observed in males than in females (SEKIKAWA et al., 1987) and the size of the metacone was also larger in males (KANAZAWA et al., 1983). These observations imply, therefore that the formation of the cuspal ridge might be dependent on the size of the cusps.

The oblique ridge in human dentition is formed by continuation of the central ridge of the metacone and the distal accessory ridge of the protocone. Ordinarily, this pattern of formation shows little variation. In the permanent first molars of Japanese subjects, however, cases of incorporation of the distal accessory ridge of the metacone into the oblique ridge were found about 12\% (SEKIKAWA et al., 1987). In the present study, this irregular pattern of the oblique ridge was observed in only one case in females. However, a small tubercle on the oblique ridge (usually located on the metacone side) was sometimes observed. This tubercle was similar to the metaconule in its position and morphology although, from a general phylogenetic point of view, the metaconule is considered to have disappeared from human dentition. According to KORENHOF (1960), however, the oblique ridge was composed of four elements, namely a distobuccal protocone ridge (distal accessory ridge), a lingual metaconule ridge, a mesiobuccal metaconule ridge and a lingual metacone ridge (central ridge). Moreover, he provided an illustration summarizing the homologous structural features in the upper molars of Paleocene prosimian primates and recent man. In his illustration, the distal accessory ridge of the protocone forming the oblique ridge did not vary, while the central ridge of the metacone in recent man contained the element of a mesiobuccal metaconule ridge phylogenetically.

BIGGERSTAFF (1975) proposed the concept of basal crown areas to investigate the variation within molar crowns by deviations in the size of individual crown components. He measured the lower first molar crown and found that a molar with a distal fovea and distal marginal ridge was larger than molars without these structures. Similarly, we also found a size difference between 
teeth with and without a well developed metaconule. Teeth with a metaconule showed larger crown sizes compared with those without. The opposite applied to cusp heights, however (Table 2). In other words, a large but low cusped molar, which showed a small inclination of cusp ridge, tended to have a well developed metaconule (Fig. 4). The explanation for this is unclear but if the metaconule were present in the enamel dentine junction in groups both with and without a metaconule, and enamel thickness were the same in both groups, it could be argued that the presence of a metaconule on the enamel surface might be unclear in the molar with larger cusp ridge inclination. This would imply that the degree of development of the occlusal tubercles (i.e. the metaconule, mesial tubercle, sixth and seventh cusp) might be related to the overall crown size, occlusal surface size and/or cusp height.

There is evidence of this in the permanent dentition where the frequency of appearance of the sixth cusp, which is one of the occlusal tubercles, is high in Australian Aboriginals, who have one of the largest molars among modern human populations (HANIHARA, 1970; TOWNSEND et al., 1988. BROWN et al., 1980). When upper permanent first and deciduous second

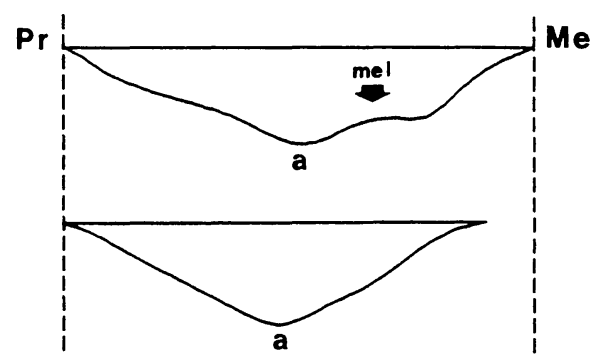

Fig. 4. Schematic representation of the mean vertical features of the oblique ridge. a, the deepest point of the oblique ridge; mel, metaconule; upper, average for molars with mel $(n=16,++)$; lower, without mel $(n=8,-)$. molars are compared, the size of the crown is larger in permanent molars than in deciduous molars. In spite of this size difference, the frequency of appearance of the metaconule is greater in the deciduous molars of Japanese subjects (HANIHARA, 1956). This is generally considered to be because the deciduous teeth have more primitive characteristics than the permanent teeth, but could also be related to the thinner enamel of deciduous molars (FINN, 1973). SHELLIS (1984) investigated the rate at which enamel formation extends over the crown during tooth development in deciduous and permanent dentitions and pointed out that the mean enamel extension rate was about five times greater in deciduous than permanent teeth. Thinner enamel and faster enamel extension rate in deciduous dentition would suggest that the morphology of the deciduous molar crown was clearer reflection of the underlying enamel dentine junction than in the slower-developing, thicker enameled, permanent molars.

In addition, KRAUS (1959) analyzed the rate of enamel deposition and found that there are differential rates of appositional growth. Moreover, CHRISTENSEN (1967) studied the human molar tooth buds obtained from 71 human foetuses and concluded that a small tubercle on the enamel dentine junction appeared to lose its identity as appositional growth occurred. SAKAI et al. (1971) reported also that some molars had the CARABELLI cusp on the enamel dentine junction without the appearance of the tubercle on the enamel surface. These results, when related to the present study, suggest that the development of the metaconule might be related to the enamel thickness at its location. The relative degree of enamel deposition in various crown regions therefore appears to be an important determinant of external tooth morphology. 


\section{Acknowledgements}

We express our gratitude to Professor $T$. Brown of the Department of Dentistry, The University of Adelaide, South Australia for his valuable comments on the manuscript. We wish to thank Mrs. S. HASTINGS who attended to manuscript preparation. This study was supported in part by a Grant-in-Aid for Scientific Research from the Ministry of Education, Science and Culture in Japan (No. 61771422) and also by a grant from the Nihon University School of Dentistry at Matsudo, Japan.

\section{抄録}

日本人上靧第 2 乳臼歯の咬頭隆線

関川三男・金沢英作・尾嵭 公 $\cdot$ L. C. RICHARDS

上顎第 2 乳田菊（男子：22, 女子：31）咬合面のモ アレ写真から各咬頭の隆線の出現頻度之平均的な走行 パターンを定量的に調査した。さらに，すでに得られ ている上顎第 1 大臼歯での結果と比較した。中隆線 は，すべての歯の各咬頭に認められたが, hypoconeに は存在しないものもある。また，近心および遠心の副 隆線は, hypocone と metacone では発達の弱いものや あるいは欠如することもある。男女間で隆線の出現頻 度や平均的な走行パターンにあまり大きな差は認めら れない.しかし, metaconeの近心副隆線は，女子の方 が男子より有意に出現頻度が高い。隆線の平均的な走 行パターンは, trigonの大きさを基準化した斜行座標 から mesh data として得た. trigonを構成する咬頭で は，それぞれ3つの隆線は基本的に［山］の字型の走 行パターンを示す.しかし, hypoconeでは定形的なパ ターンは認められない，すなわち，第2 乳臼菌の隆線 の形態においても，第 1 大臼歯で得られた結果と同様 に hypocone の形態変異が著しいといえる.

斜走隆線の走行は, 肉眼的に第 2 乳臼菌のほらが第 1 大臼歯より明瞭である. 斜走隆線は, 男女ともにす べての歯に認められたが，斜走隆線の最深点（中心溝 との会合部）の高さやこの隆線上に見られる小結節の 発達程度，さらにそこから派生する細い隆線には変異 が認められた。この小結節は, 通常 metacone の中心 隆線上に見られ，その位置や到態が metaconule に類
似する。この小結節の発達の良い歯は，そらでないも のと比べて咬頭頂間距離は大きいが，咬頭は低い傾向 を示す。第 2 乳臼苗に比へ咬頭が高くエナメル質の厚 い第 1 大臼歯では，この結節はほとんど認められな い,すなわち，咬合面に存在する隆線や結節の発達程 度は，咬頭の大きさや高さと関連をもち，さらにエナ メル質の形成量にも依存していることが推察された。

\section{References}

ASH, M.M., 1984: WHEELER's Dental Anatomy, Physiology and Occlusion. W.B. Saunders, Philadelphia.

BIGGERSTAFF, R.B., 1975: Cusp size, sexual dimorphism and heritability of cusp size in twins. Am. J. Phys. Anthropol., 42: 127-140.

BROWN, T., B. MARGETTS and G.C. TOWNSEND, 1980: Comparison of mesiodistal crown diameters of the deciduous and permanent teeth in Australian Aboriginals. Aust. Dent. J., 25: 28-33.

BUTLER, P.M., 1955: The ontogeny of molar pattern. Biological Review, 31: 30-70.

CHRISTENSEN, G.J., 1967: Occlusal morphology of human tooth buds. Archs. oral Biol., 12: 141-149.

DAHLBERG, A.A., 1949: The dentition of the American Indian. In: W.S. LAUGHLINE (Ed.), Physical Anthropology of the American Indian, pp. 138-176. Vinking Fund, New York.

FINN, S.B., 1973: Clinical Pedodontics, 4th ed. W.B. Saunders, Philadelphia, pp. 45-57.

HANIHARA, K., 1956: Studies on the deciduous dentition of the Japanese and the Japanese-American hybrids, 4. Deciduous upper molars. J. Anthrop. Soc. Nippon, 65: 67-87. (In Japanese with English summary)

HANIHARA, K., 1970: Mongoloid dental complex in the deciduous dentition with special reference to the dentition of the Ainu. J. Anthrop. Soc. Nippon, 78: 3-17.

JAARADA, M.J., J.A. CLAYTON and G.E. MYERS, 1978: Measurement of cusp height and ridge and groove direction using an electron transducer. II. Pantographics and the terminal hinge axis. J. Pros. Dent., 40: 83-88.

KAMIJOU, Y., 1977: Anatomy of Permanent Dentition in Japanese. Anatomu, Tokyo. (In Japanese)

[上條雍彦, 1977 : 日本人永久歯解剖学, アナトー 么社, 東京.]

KANAZAWA, E., M. SEKIKAWA and T. OZAKI, 1983: Three-dimensional measurements of the occlusal surface of upper molars in a modern Japanese population. Acta anat., 116: 90-96.

KanAZAWA, E., M. SEKIKAWA and T. OZAKI, 1984: 
Three-dimensional measurements of the occlusal surfaces of upper molars in a Dutch population. J. Dent. Res., 63: 1298-1301.

KANAZAWA, E., D.H. MORRIS, M. SEKIKAWA and T. OZAKI, 1988: Comparative study of the upper molar occlusal table morphology among seven human populations. Am. J. Phys. Anthropol., 77: 271-278.

KORENHOF, C.A.W., 1960: Morphogenetical aspects of the human upper molar. Uitgeversmaatschappij Neerlandia, Utrecht.

KRAUS, B.S., 1952: Morphologic relationship between enamel and dentin surfaces of lower first molar teeth. J. Dent. Res., 31: 248-256.

LAVELLE, C.L.B., 1978: An analysis of molar tooth form. Acta anat., 100: 282-288.

OZAKI, T., E. KANAZAWA and M. SEKIKAWA, 1984: Three-dimensional measurement of the occlusal surface of lower first molars in a Dutch population. Jpn. J. Oral Biol., 26: 241-248.

OZAKI, T., E. KANAZAWA, M. SEKIKAWA and J. AKAI, 1987: Three-dimensional measurements of the occlusal surfaces of the upper molars in Australian Aboriginals. Aust. Dent. J., 32: 263-269.

OZAKI, T., J. AKAI, M. SEKIKAWA and E. KANAZAWA, 1988: Three-dimensional measurement of the occlusal surface of the deciduous upper second molar in Japanese population. Jpn. J. Oral Biol., 30: 834-840.

SAKAI, T. and H. HANAMURA, 1971: A morphological study of enamel-dentin border on the Japanese dentition. V. Maxillary molar. J. Anthrop. Soc., Nippon, 79: 297-322. (In Japanese with English summary)

SAKURA, H., 1980: Variations of fovea anterior in upper molars among some fossil and recent hominids. Bull. Nat. Sci. Mus. Tokyo, Ser. D, 6: 1-8.

SEKIKAWA, M., J. AKaI, E. KanaZAWA and T. OZAKI, 1986: Three-dimensional measurement of the occlusal surfaces of lower first molars of Australian Aboriginals. Am. J. Phys. Anthropol., 71: 25-32.

SEKIKAWA, M., E. KANAZAWA and T. OZAKI, 1987: Study of the cuspal ridges of the upper first molars in a modern Japanese population. Acta. anat., 129: 159-164.

SEKIKAWA, M., E. KANAZAWA and T. OZAKI, 1988a: Cusp height relationships between the upper and lower molars in Japanese subjects. J. Dent. Res., 67: 1515-1517.

SEKIKAWA, M., E. KanAZAWA, T. OZAKI and T. BROWN, 1988b: Principal component analysis of intercusp distances on the lower first molars in three human populations. Archs. oral Biol., 33: 535-541.

SHELLIS, R.P., 1984: Variations in growth of the enamel crown in human teeth and a possible relationship between growth and enamel structure. Archs. oral Biol., 29: 697-705.

TOWNSEND, G.C., H. YAMADA and P. SMITH, 1989: Expression of the entoconulid (sixth cusp) on mandibular molar teeth of an Australian Aboriginal population. Am. J. Phys. Anthropol. (In press)

\section{関 川 男 日本大学松戸歯学部第一解剖学教室 干271 松戸市栄町西 2-870-1}

Mitsuo SEKIKAwA Department of Anatomy, Nihon University School of Dentistry at Matsudo 2-870-1 Sakae, Matsudo, Chiba 271, Japan 